\title{
HUBUNGAN USIA IBU DENGAN KEJADIAN BERAT BAYI LAHIR RENDAH
}

\section{CORRELATION OF MOTHER AGE WITH LOW BIRTH WEIGHT}

\author{
Dwi Herman Susilo \\ Akademi Kebidanan Ibrahimy Sukorejo Situbondo \\ Email: dwihermansusilo@akbidibrahimy.ac.id
}

\begin{abstract}
ABSTRAK
Berat bayi lahir rendah adalah bayi yang lahir dengan berat lahir kurang dari 2500 gr tanpa memandang masa gestasi yang di timbang dalam 1 jam setelah lahir. Berat bayi lahir rendah sampai saat ini masih merupakan penyebab mortalitas (kematian) dan morbilitas (kesakitan) pada masa neonatal (bayi umur 0 - 28 hari). Desain penelitian yang digunakan adalah pendekatan cross sectional. Dengan populasi semua bayi yang lahir di wilayah kerja puskesmas banyuputih kabupaten situbondo sebanyak 818 bayi, sampel penelitian sebanyak 164 bayi dengan dengan metode sampling menggunakan teknik proportionate atratifed random. Teknik pengambilan data dengan medical record, dilaksanakan pada bulan Mei 2015. Pengolahan dan analisa data menggunakan uji statistic yaitu uji koefesien contingensi dengan tingkat kemaksimalan $\alpha<0,05$. Hasil penelitian menunjukkan bahwa diperoleh hasil nilai $\mathrm{p}=0,00$ yang artinya ada hubungan yang signifikan antara Usia ibu dengan berat bayi lahir rendah di wilayah kerja puskesmas banyuputih Kabupaten Situbondo.
\end{abstract}

Kata Kunci : Usia Ibu, Berat Bayi Lahir Rendah

\section{ABSTRACT}

Low birth weight is a baby born with less than 2500 grams of birth weight regardless of gestational weighing in 1 hour after birth. Low birth weight is still the cause of mortality (death) and morality (pain) during neonatal period (infants aged $0-28$ days). Research design used was cross sectional approach. With the population of all babies born in the work area of puskesmas banyuputih of Situbondo district as many as 818 babies, Sample in this study as many as 164 babies with the sampling method using proportionate atratifed random technique. Technique of taking data with medical record, executed in May 2015. Processing and data analysis using statistic test that was contingency coefficient test with level maximize a $<0,05$. The results showed that the results obtained $p$ value $=0.00$ which means there is a significant correlation of the mother age with low birth weight $n$ the work area of puskesmas banyuputih Situbondo regency.

Keywords : Mother Age, Low Birth Weight

\section{PENDAHULUAN}

BBLR adalah bayi yang lahir dengan berat badan kurang dari 2.500 gram tanpa memandang masa kehamilan(proverawati, 2010). Banyak faktor yang mempengaruhi terjadinya
BBLR diantaranya ialah usia ibu ketika hamil (Anggarani, 2013).

Bayi dengan berat badan lahir rendah (BBLR) hingga saat ini masih merupakan masalah di seluruh dunia karena merupakan penyebab kesakitan 
dan kematian pada masa bayi baru lahir. Prevelensi BBLR diperkirakan $15 \%$ dari seluruh kelahiran di dunia dengan batasan $3,3 \%-38 \%$ dan lebih sering terjadi di Negara-negara berkembang atau sosioekonomi rendah. Statistik menunjukkan bahwa $90 \%$ dari kejadian BBLR didapatkan di Negara berkembang dan angka kematiannya 35 kali lebih tinggi dibanding pada bayi dengan berat lahir lebih dari 2500 gram(proverawati, 2010).

Berdasarkan Survey Demografi dan kesehatan Indonesia (SDKI) tahun 2012 menyatakan bahwa angka kematian bayi di Indonesia pada saat ini adalah 32 per 1000 kelahiran hidup, 19 per 1000 kehidupan terjadipada masa neonatal dini sampai usia 28 hari (SDKI, 2012).

Di Jawa Timur AKB tahun 2007 sebesar 35 per 1000 kelahiran hidup. Menurut data BPS (Badan Pusat Statistik) AKB Provensi Jawa timur tahun 2009 sebesar 31,41 per 1000 kelahiran hidup. Pada tahun 2010 angka kematian bayi terdapat 29,99 per 1000 kelahiran hidup tahun 2011 angka kematian bayi sebanyak 29,24 per 1000 kehidupan hidup dan angka kematian bayi 30 per 1000 kelahiran hidup di tahun 2012. Angka kematian bayi pada tahun 2012 menunjukkan adanya peningkatan dan penurunan namun masih jauh dari target MDG's 2015 yaitu 23 per 1000 kehidupan. Posisi pertama penyebab kematian bayi di jawa timur yaitu BBLR sebesar 38,03\% (Profil Kesehatan Jwa Timur, 2013). Dari hasil yang di peroleh dari Dinas Kesehatan Situbondo bayi yang mengalami BBLR di tahun 2014 sebanyak $5.75 \%$.

Penyebab terjadinya bayi BBLR secara umum bersifat multifaktorial, sehingga kadang mengalami kesulitan untuk melakukan tindakan pencegahan. Penyebab terbanyak terjadinya bayi BBLR adalah kelahiran premature(proverawati, 2010). Dan prematur kebanyakan terjadi pada ibu hamil yang usianya terlalu muda (Anggarani, 2013). Dari hasil stadi pendahuluan di wilayah kerja Puskesmas Banyuputih Situbondo terdapat 55 kasus berat badan lahir rendah.

\section{METODE PENELITIAN}

Penelitian ini menggunakan desain penelitian analitik dengan pendekatan cross sectional. Populasi dalam penelitian ini adalah semua bayi yang lahir di wilayah kerja Puskesmas Banyuputih sebanyak 818 bayi. Sampel dalam penelitian ini sebanyak 164 bayi 
dan tercatat dalam rekam medik di

Puskesmas Banyuputih. Penelitian ini dilaksanakan di wilayah kerja Puskesmas Banyuputih Situbondo. Waktu Penelitian dilaksanakan pada bulan September 2016 sampai Februari 2017. Instrumen dalam penelitian ini menggunakan Medical record. Analisis data dengan menggunakan uji Koefisien Cotingensi.

\section{HASIL DAN PEMBAHASAN}

Berdasarkan hasil uji statistik didapatkan hasil sebagaimana tabel 1 .

\begin{tabular}{|c|c|c|c|}
\hline \multirow[t]{3}{*}{ Tabel } & \multirow{2}{*}{$\begin{array}{l}\text { 1. Distribusi } \\
\text { Berdasarkan }\end{array}$} & \multicolumn{2}{|c|}{ Frekuensi } \\
\hline & & xan Usia & Hamil di \\
\hline & \multicolumn{3}{|c|}{ Wilayah Kerja Puskesmas Banyuputih } \\
\hline No & Usia ibu & Frekuensi & Persentase \\
\hline 1 & $<20$ & 48 & $29,2 \%$ \\
\hline 2 & $20-35$ & 80 & $48,8 \%$ \\
\hline \multirow[t]{2}{*}{3} & $>35$ & 36 & $22 \%$ \\
\hline & Jumlah & 164 & $100 \%$ \\
\hline
\end{tabular}

Berdasarkan tabel 1. Dapat diketahui berdasarkan umur responden hampir seluruhnya berusia 20-35 tahun yaitu $80(48,8 \%)$ orang dan sebagian kecil pada ibu yang berusia $>35$ tahun yaitu $36(22 \%)$.

Tabel 2. Distribusi Frekuensi Responden Berdasarkan Berat Badan Bayi Saat Lahir di Wilayah Kerja Puskesmas Banyuputih.

\begin{tabular}{clcc}
\hline No & BB bayi & Frekuensi & Persentasi \\
\hline 1 & BBLR & 56 & $34 \%$ \\
2 & Normal & 108 & $66 \%$ \\
& Jumlah & 164 & $100 \%$ \\
\hline
\end{tabular}

Berdasarkan tabel 2 Dapat diketahui berdasarkan berat badan bayi saat lahir hampir setengahnya adalah bayi dengan berat badan kurang dari 2500 yaitu $56(34 \%)$ bayi.

Tabel 3. Distribusi Silang Tentang Usia Ibu Dengan Berat Badan Bayi Saat Lahir di Wilayah Kerja Puskesmas

\begin{tabular}{cccccccc}
\hline \multirow{2}{*}{ No } & \multirow{2}{*}{ Usia Ibu } & BBLR & \% & Normal & \% & Usia & jumlah \\
\hline 1 & & 29 & 18,0 & 19 & 12,0 & 48 & 29,0 \\
2 & 20 & 4 & 2,4 & 76 & 46,0 & 80 & 49,0 \\
3 & $>35$ & 23 & 14,0 & 13 & 8,0 & 36 & 22,0 \\
& Jumlah & 56 & 34 & 108 & 66 & 164 & 100 \\
\hline
\end{tabular}


Berdasarkan tabel 5.3 Dapat diketahui sebagian kecil dari yang berusia kurang dari 20 tahun memiliki bayi berat badan lahir rendah (BBLR) yaitu sebanyak $29 \quad(18,0)$ dan hampir setengahnya yaitu responden yang melahirkan bayi dengan berat badan normal yaitu berusia diantara $20-35$ tahun yaitu 76 (46,0\%).

Dari hasil tersebut dilakukan uji koofesien kontingensi untuk mengetahui keterkaitan antara usia ibu dengan kejadian berat badan lahir rendah, diperoleh hasil uji $\mathrm{p}=0,00(<0,05)$ sehingga $\mathrm{H}_{1}$ diterima yang artinya ada hubungan antara usia ibu dengan kejadian berat badan lahir rendah.

Usia merupakan umur seseorang sejak ia lahir sampai saat ini. Usia juga dapat menentukan seseorang itu dalam katagori resiko tinggi atau dapat menentukan masa yang aman untuk kehamilan. Hampir setengah ibu hamil merencanakan pada usia 20 sampai 35 tahun, dan tidak menutup kemungkinan ada yang merencanakan di usia yang terlalu muda dan terlalu tua.

Menurut besarnya penyebab kelahiran BBLR dapat dibagi menjadi empat factor yaitu. 1) factor ibu (penyakit, komplikasi pada kehamilan, usia ibu), 2) factor kebiasaan ibu (merokok, minum, minuman beralkohol), 3)faktor janin (hidramnion, kembar), 4) faktor lingkungan. (Saputra, 2014).

Dari hasil penelitian bahwa jumlah bayi BBLR di wilayah kerja puskesmas banyuputih hampir setengah dari 164 sempel yang mengalami BBLR yaitu $56(34 \%)$ bayi.

Peran reproduksi terutama pada rahim yang belum siap mendapat beban selama proses kehamilan serta sel telur yang belum sempurna akan mengganggu perkembangan janin dalam rahim. Kehamilan merupakan suatu masa yang sangat penting untuk dijaga kesehatannya karena kondisi bayi saat lahir sangat ditentukan pada massa kehamilannya.

Menurut Anggraini (2013) salah satu faktor yang mempengaruhi terjadinya BBLR adalah dari usia ibu. Kehamilan pada usia muda merupakan faktor resiko karena organ reproduksi belum matang dan belum siap untuk dibuahi (Hamil) sehingga dapat merugikan kesehatan ibu dan menghambat perkembangan dan pertumbuhan janin yang dikandung. Kehamilan di usia tua sangat berpengaruh terhadap kondisi ibu karena pada usia ini kesehatan ibu sudah mulai menurun, jika 
kondisi ibu menurun hal ini juga akan berpengaruh terhadap janin yang dikandung.

Dari hasil distribusi silang dapat di ketahui sebagian kecil yang berusia kurang <20 tahun memiliki bayi berat badan lahir rendah yaitu sebanyak 29 $(18,0 \%)$ dan hampir setengahnya dari responden yang melahirkan dengan berat badan lahir normal yaitu berusia antara 20 - 35 tahun yaitu 76 (46,0\%) Dari hasil tersebut dilakukan uji untuk mengetahui keterkaitan antara usia ibu dengan berat badan lahir ringan, berdasarkan hasil uji statistic dengan menggunakan koefision kontingensi $\mathrm{p}=0,00 \quad(<\quad 0,05) \quad$ dapat disimpulkan bahwa ada hubungan antara usia ibu dengan berat badan lahir ringan.

Pertumbuhan janin dalam kandungan sangat dipengaruhi oleh kondisi ibu. Semakin muda atau semakin tua usia ibu di saat hamil maka semakin tinggi resiko yang akan terjadi baik pada ibu maupun pada janin. Perbedaan usia menunjukkan perbedaan kondisi fisik. Semua ibu dapat merencanakan kehamilannya kapan saja namun di saat ibu berusia dibawah 20 tahun, organ reproduksi belum sempurna seutuhnya.

Jika ibu hamil di usia ini banyak kemungkinan resiko yang akan terjadi baik pada ibu maupun pada janin yang dikandung, karena masa kehamilan sangat berperan penting terhadap bayi yang akan dilahirkan kelak. kondisi fisik ibu hamil dengan usia lebih dari 35 tahun juga akan sangat menentukan proses kehamilannya. hal ini juga mempengaruhi kondisi janin karena pada proses pembuahan, kualitas sel telur wanita usia ini sudah menurun jika dibandingkan dengan sel telur pada wanita dengan usia reproduksi sehat. Dari hasil penelitian dan teori yang di dapat banyak resiko yang akan terjadi pada ibu hamil dengan resti.

\section{SIMPULAN DAN SARAN}

Berdasarkan hasil penelitian didapatkan hasil ada hubungan antara usia ibu dengan kejadian berat badan lahir rendah. Dari penelitian ini diharapkan dapat memperluas pengetahuan, menambah pemahaman terkait faktor penyebab terjadinya BBLR sehingga upaya pencegahan dapat dilakukan.

\section{DAFTAR PUSTAKA}

Anggarani, D. R. 2013. Kupas Tuntas Seputar Kehamilan. Jakarta: Agromedia pustaka. 
128 OKSITOSIN, KEBIDANAN, VOL. IV, NO. 2, AGUSTUS 2017: 123-128

Profil Jawa Timur. 2013. (online), (www. Prifil Jawa Timur. pdf. diakses pada tanggal 13 April 2015)

Proverawati, A. 2010. Berat Badan Lahir

Rendah. yogyakarta: nuha medika
Saputra, D. 2014. pengantar asuhan neonatus, bayi, dan balita. tanggerang selatan: Binarupa Aksara

SDKI (Survey Demografi Kesehatan Indonesia), 2012 